\title{
Critical lengths, mortality rates and relative yield per recruit of the common sole Solea solea from the Egyptian Mediterranean coast off Alexandria
}

\author{
Sahar F. Mehanna ${ }^{1}$, Mohamed Abo Elregal ${ }^{2}$ and Noha M. Aid ${ }^{1}$ \\ 1- Fish Population Dynamics Lab, National Institute of Oceanography and \\ Fisheries, Egypt \\ 2- Marine Sciences Department, Faculty of Science, Port Said University, Egypt.
}

\section{ABSTRACT}

Mortality rates of the common sole Solea solea from Alexandria were estimated based on the von Bertalanffy growth parameters obtained by the same authors as Lo $=34.77 \mathrm{~cm} ; \mathrm{K}=0.55$ year $^{-1}$ and $\mathrm{t}_{0}=0.07$ years for males, $\mathrm{L} \infty=36.24 \mathrm{~cm} ; \mathrm{K}=0.63$ year $^{-1}, \mathrm{t}_{0}=-0.01$ years for females and $\mathrm{L} \infty=35.1 \mathrm{~cm} ; \mathrm{K}=0.58$ year $^{-1}$ and $\mathrm{t}_{0}=0.003$ years for sexes combined during two fishing seasons (2011-2013). The total, natural and fishing mortalities were $2.09,0.52$ and 1.57 year $^{-1}$ respectively for males, 1.75, 0.53 and 1.22 year $^{-1}$ respectively for females and $1.7,0.52$ and 1.18 year $^{-1}$ respectively for sexes combined. Correspondingly, the exploitation ratio was $\mathrm{E}=$ $0.75,0.7$ and $0.69 / y$ for males, females and sexes combined respectively. The estimated length at first capture $\mathrm{L}_{\mathrm{c}}$ was $15.97,12.72$ and $14.22 \mathrm{~cm}$ for males, females and sexes combined, respectively while the length at first maturity $\mathrm{L}_{\mathrm{m}}$ was 15.31 , 15.87 and $15.98 \mathrm{~cm}$ for males, females and sexes combined, respectively. These results reflect the high level of the exploitation. The relative yield per recruit analysis showed that the stock of $S$. solea is over exploited and needs urgent management regulations to conserve this potential fishery.

Keywords: Alexandria; Soleidae, Solea solea, Mortality rates; per-recruit analysis; fisheries management.

\section{INTRODUCTION}

The Egyptian Mediterranean coast is about $1100 \mathrm{~km}$, extending from El-Sallum in the West to El-Arish in the East. The fishing grounds along the Egyptian Mediterranean coast are divided into 4 regions: Western region (Alexandria and ElMex, Abu-Qir, Rasheed, El-Maadiya, and Mersa Matruh), Eastern region (Port Said and El-Arish), Demietta region and Nile Delta region. The western region constitutes about $39 \%$ of the total catch from the Egyptian Mediterranean, from which Alexandria and El-Mex is the most productive fishing ground, providing up to $53 \%$ of the total fish production in the western region (GAFRD annual reports).

The common sole Solea solea, which locally is known as Mousa is one of the most important commercial fish species in Alexandria coast. The soles assume a very important place in the Egyptian Mediterranean fisheries. Soles in the Egyptian Mediterranean are exploited mainly by trawling and a small part of catch is caught by kannar and trammel nets. The population parameters of the common sole in the Egyptian waters are sparsely studied specially in Alexandria region (El-Gammal et al., 1995; Mehanna and Salem, 2012; Salman, 2014; Mehanna et al., 2011, 2014 \& 2015). So, the present study aims at determining the critical lengths, mortality and exploitation rates and relative yield per recruit of the common sole Solea solea in Alexandria as a basic parameters for its management. 


\section{MATERIALS AND METHODS}

\section{Growth parameters}

Derived from Mehanna et al. (2015).

\section{Critical lengths}

\section{Length at recruitment}

The length at recruitment $\left(\mathrm{L}_{\mathrm{r}}\right)$ was determined as the smallest sole specimen in the catch.

\section{Length at first capture}

The length at first capture $\left(\mathrm{L}_{\mathrm{c}}\right)$; the length at which $50 \%$ of the common sole retained in the gear was estimated by the analysis of catch curve using the method of Pauly (1984).

\section{Length at first sexual maturity}

The length at first sexual maturity $\left(\mathrm{L}_{\mathrm{m}}\right)$; the length at which $50 \%$ of sole reach their sexual maturity was estimated by fitting the percentage maturity against mid lengths. $\mathrm{L}_{\mathrm{m}}$ was estimated as the point on $\mathrm{X}$-axis corresponding to $50 \%$ point on $\mathrm{Y}$ axis.

\section{Mortality and exploitation rates}

Total mortality coefficient ( $\mathrm{Z}$ ) was estimated as the geometric mean of three different methods; Ricker (1975), Jones and Van Zalinge, (1981) and Pauly, (1983), while the natural mortality coefficient (M) was estimated as the geometric mean of the methods; Tanaka (1960), Ursin (1967) and Pauly (1980). The fishing mortality coefficient was estimated by subtracting the value of natural mortality coefficient from the value of total mortality coefficient as follows: $\mathrm{F}=\mathrm{Z}-\mathrm{M}$ and the exploitation ratio was estimated by the formula suggested by Gulland (1971) as $E=F / Z$.

\section{Relative Yield per Recruit (Y/R)'}

The relative yield per recruit (Y/R)' and the relative biomass per recruit $(B / R)^{\prime}$ were estimated by using the model of Beverton and Holt (1966) as modified by Pauly and Soriano (1986) and incorporated in FiSAT software.

\section{RESULTS AND DISCUSSION}

\section{Growth parameters}

The von Bertalanffy theoretical growth in length equations for $S$. solea from Alexandria waters of Mediterranean are obtained from Mehanna et al (2015) as:

Males $\mathrm{L}_{\mathrm{t}}=34.77\left(1-\mathrm{e}^{-0.55(\mathrm{t}-0.06926)}\right)$

Females $\mathrm{L}_{\mathrm{t}}=36.24\left(1-\mathrm{e}^{-0.62\left(\mathrm{t}_{-} 0.00955\right)}\right)$

Sexes combined $L_{t}=35.81\left(1-e^{-0.58(t+0.00295)}\right)$

Where $L_{t}$ is the length at age $t$

\section{Critical lengths}

\section{Length $\left(L_{r}\right)$ at recruitment}

The smallest total length in the length frequency distribution of $S$. solea from Alexandria waters was 13.4 and $11.9 \mathrm{~cm}$ for males and females, respectively. These lengths are considered as the estimates of the length at recruitment.

\section{Length $\left(L_{c}\right)$ at first capture}

The length at first capture (the length at which $50 \%$ of the fish at that size are vulnerable to capture) was estimated from the catch curve of Pauly (1984). The resultant curve derived from the catch curve provided an estimate of $\mathrm{L}_{c}$ at 15.97, 12.72 and $14.22 \mathrm{~cm}$ for males, females and sexes combined, respectively (Fig.1). 


\section{Length $\left(L_{m}\right)$ at first sexual maturity}

Length at first sexual maturity $\left(\mathrm{L}_{\mathrm{m}}\right)$ has a great importance in the determination of optimum mesh size. From the maturation curve, the length at first sexual maturity of $S$. solea from Alexandria was 15.31, 15.87 and $15.98 \mathrm{~cm}$ for males, females and sexes combined, respectively. It is obvious that males matured at a slightly smaller size than females, and the estimated length at first capture was smaller than $\mathrm{L}_{\mathrm{m}}$. This means that the exploited $S$. solea must be protected in order to share the spawning activities at least once before being fished. Therefore, the mesh sizes used should be increased to catch fish of lengths greater than $17 \mathrm{~cm}$. These results are similar to the findings of Mehanna and Salem (2012) and Salman (2014) for the same species in Bardawil Lagoon.
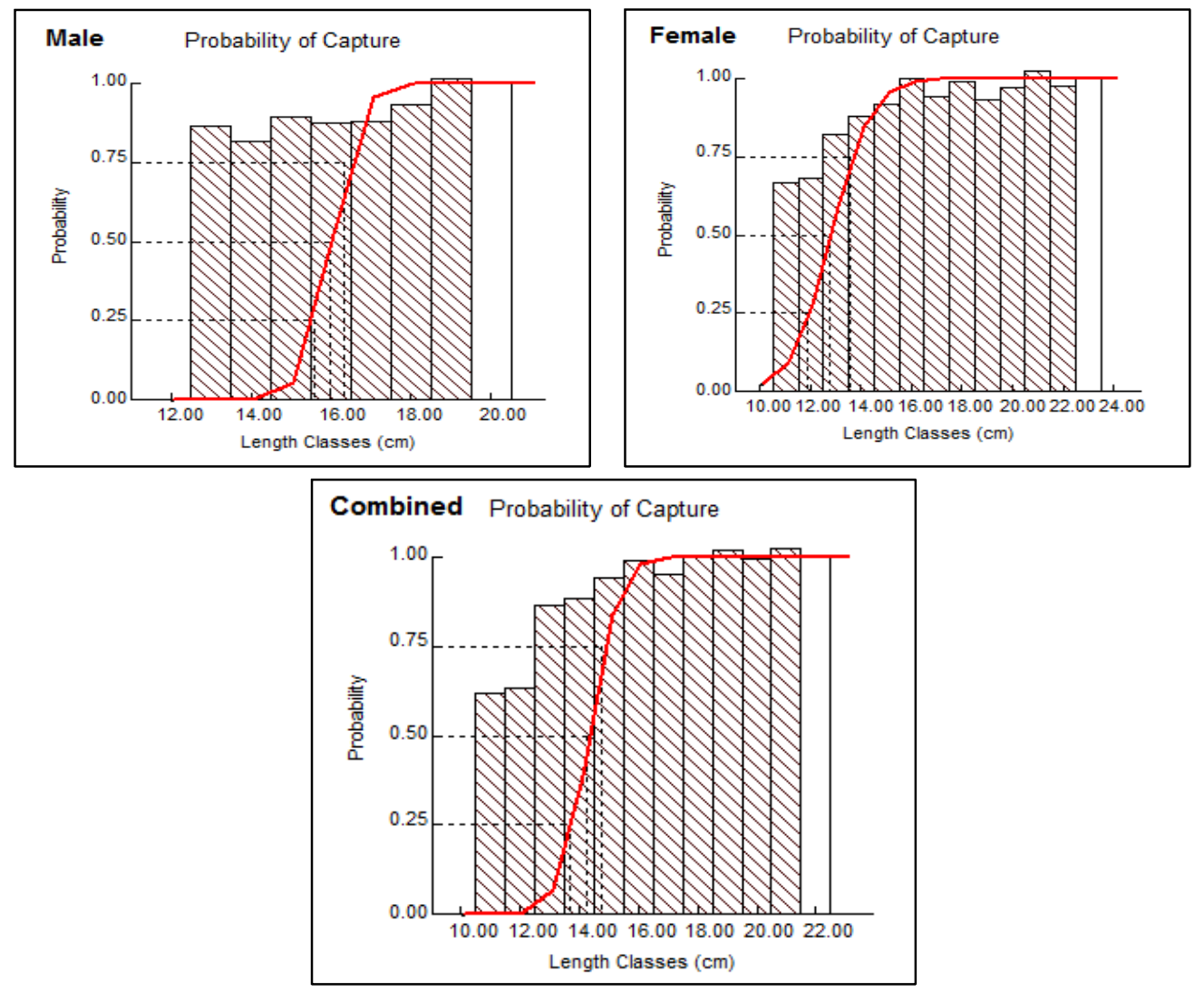

Fig. 1: Length at first capture of Solea solea from Alexandria.

\section{Mortality and exploitation rates}

The total mortality coefficient $Z$ was estimated using three different methods and the results are summarized in Table (1) and represented in Figures (2, 3 and 4). It is clear that, the $\mathrm{Z}$-values obtained from the three different methods are nearly the same, so the geometric mean of the three values will used in the subsequent calculations. While, the geometric means of the three used methods for natural mortality M estimation of $S$. solea were $0.52,0.53$ and 0.52 year for male, female and sexes combined respectively. It is obvious that, females are characterized by slightly higher M-value than males. Based on these values, the fishing mortality coefficient $\mathrm{F}$ were $1.57,1.22$ and 1.18/ year for males, females and sexes combined respectively. It is clear that, males of $S$. solea have higher fishing mortality rate than females. 
Table 1: Z estimation from the different methods for Solea solea from Alexandria.

\begin{tabular}{|l|l|l|l|}
\hline Method & Males & Females & Sexes combined \\
\hline Ricker (1975) & 1.89 & 1.61 & 1.61 \\
\hline Jones \& van Zalinge (1981) & 2.02 & 1.73 & 1.69 \\
\hline Pauly (1983) & 2.38 & 1.92 & 1.82 \\
\hline Geometric Mean & 2.09 & 1.75 & 1.70 \\
\hline
\end{tabular}

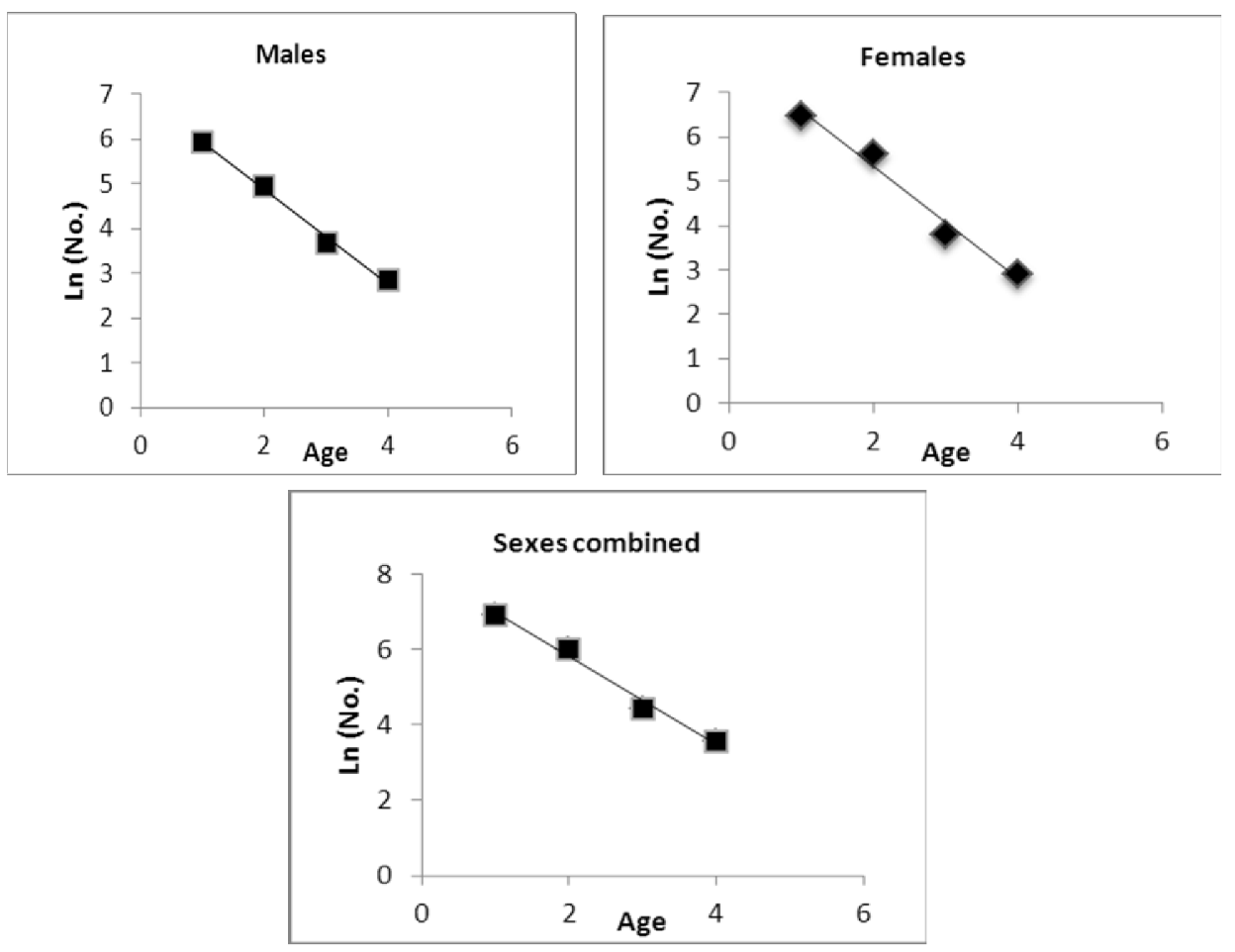

Fig. 2: Semi-logarithmic regression of Solea solea from Alexandria.

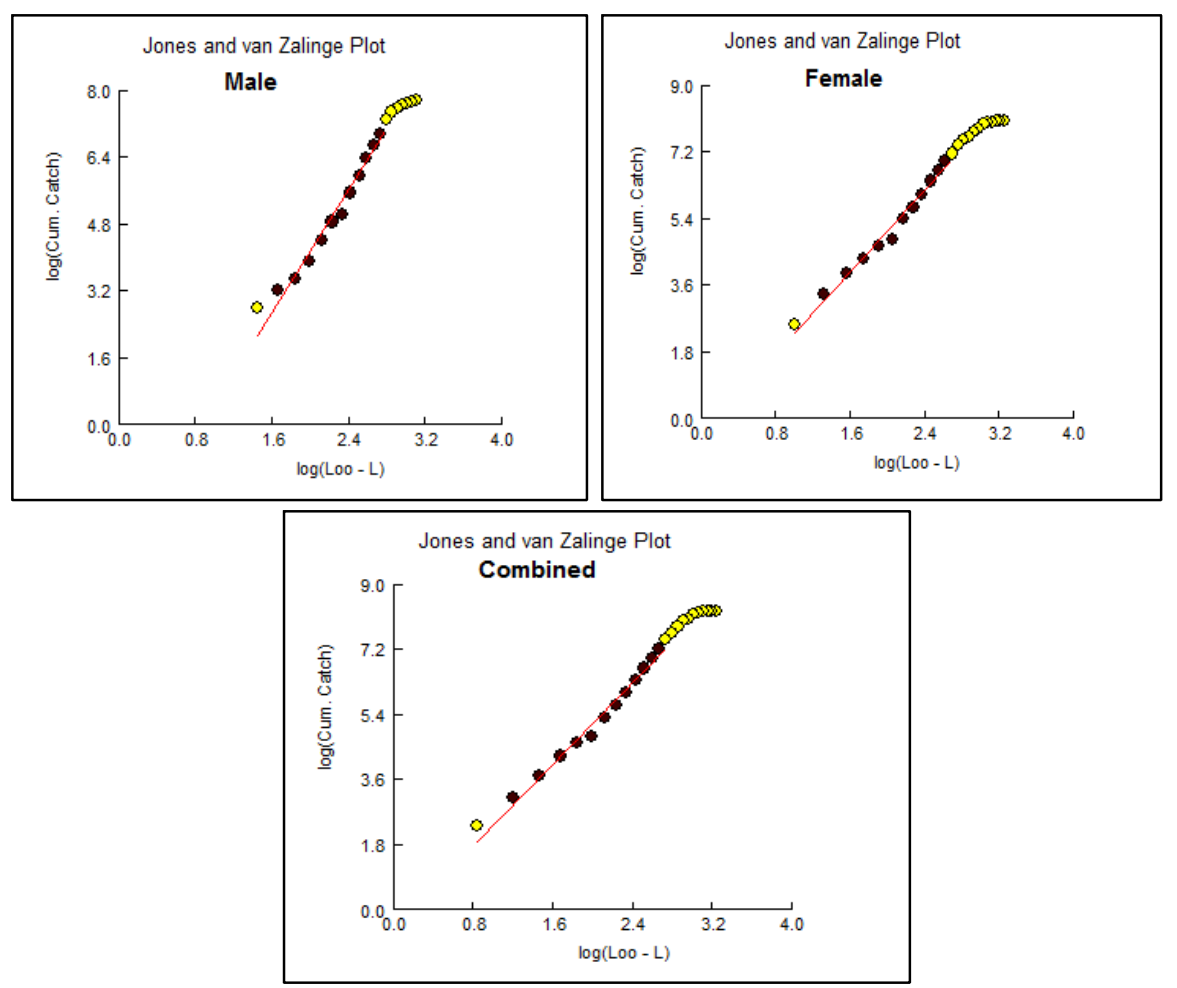

Fig. 3: Cumulated catch curve of Solea solea from Alexandria. 

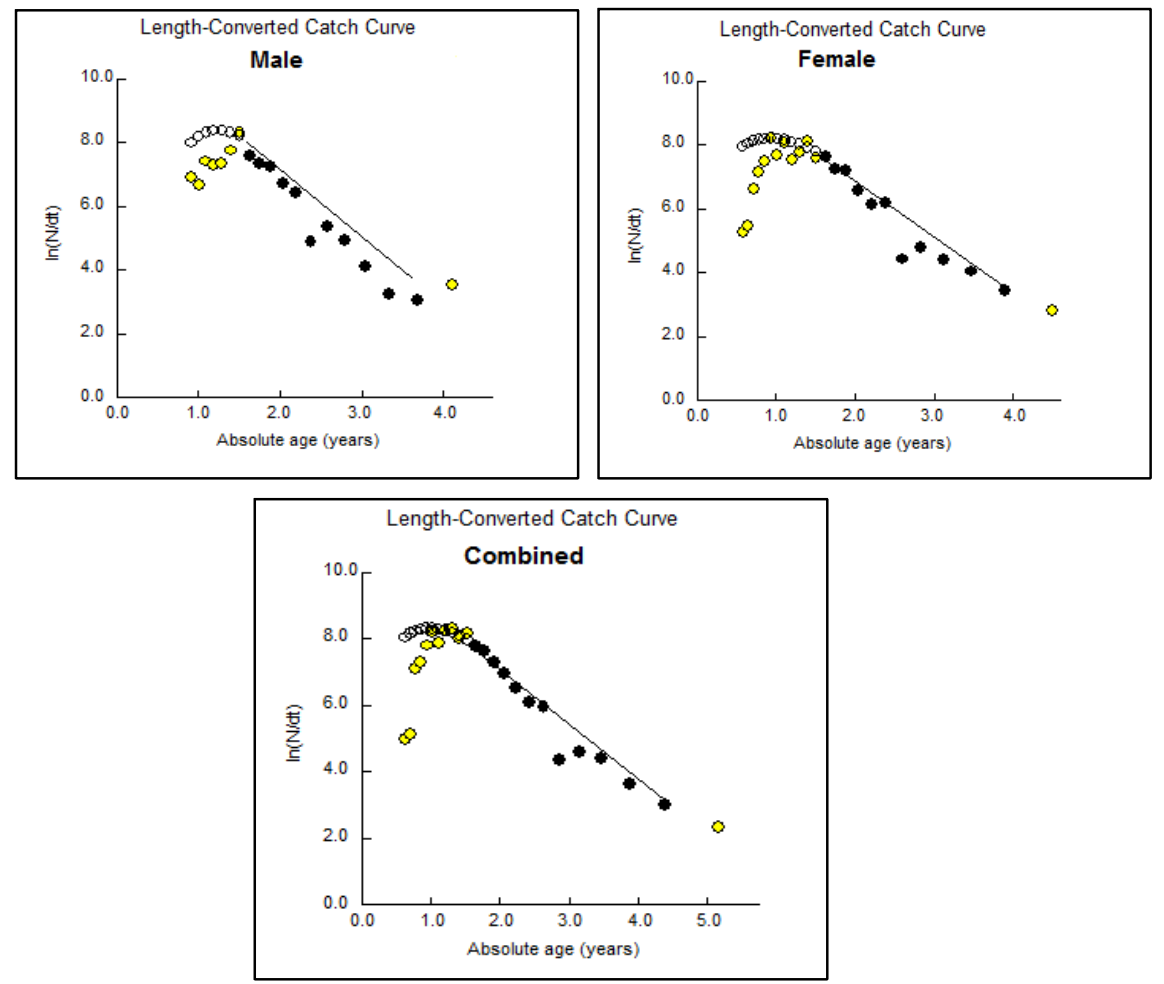

Fig. 4: Converted catch curve of Solea solea from Alexandria.

\section{Exploitation ratio (E)}

The estimated exploitation ratio for $S$. solea were $0.75,0.70$ and 0.69 / year for males, females and sexes combined respectively, which seemed to be higher than the optimum level of exploitation $(\mathrm{E}=0.5)$. From results, both of fishing mortality and exploitation rate were high indicating the high level of exploitation.

These results are in agreement with the previous studies dealing with the mortality and exploitation ratio of $S$. solea in the different Egyptian waters (Mehanna, 2007; Mehanna and Haggag, 2010; Mehanna et al., 2011; Mehanna and Salem, 2012; Mehanna et al., 2013 and Salman, 2014).

\section{Relative Yield per Recruit (Y/R)'}

The relative yield per recruit of the sexes combined of $S$. solea was estimated and the results are represented graphically in Fig. (5). The results showed that, the current exploitation rate $(\mathrm{E}=0.69 / \mathrm{y})$, length at first capture $\left(\mathrm{L}_{\mathrm{c}}=14.22 \mathrm{~cm}\right)$ and natural mortality coefficient $(\mathrm{M}=0.52 / \mathrm{y})$ didn't achieve the maximum relative yield per recruit, and the maximum yield per recruit is obtained at exploitation rate $(0.58 /$ y) which is lower than the current $\mathrm{E}$ by $15 \%$.

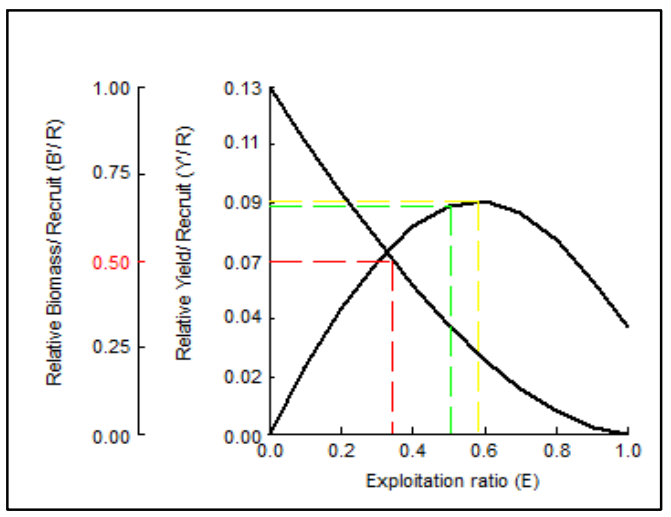

Fig. 5: Per-recruit analysis of Solea solea from Alexandria. 
This means that the present level of fishing mortality $(\mathrm{F}=1.18$ / year) was much higher than that gives the maximum (Y/R)'.

Both of $\mathrm{E}_{0.1}$ (the level of exploitation at which the marginal increase in yield per recruit reaches $1 / 10$ of the marginal increase computed at a very low value of E) and $E_{0.5}$ (the exploitation level which will result in a reduction of the unexploited biomass by $50 \%$ ) were estimated. The obtained values of $E_{0.1}$ and $E_{0.5}$ were 0.5 and 0.35 respectively. The results indicated that the present level of $\mathrm{E}(0.69)$ is higher than the exploitation rate $\left(\mathrm{E}_{0.5}\right)$ which maintain $50 \%$ of the stock biomass. This means that the present level of the exploitation should be decreased by about $49 \%$.

To evaluate the variation in yield per recruit due to change in the length at first capture $\left(\mathrm{L}_{\mathrm{c}}\right)$ which is related to the estimation of optimum mesh size, the yield per recruit of $S$. solea was calculated by using length at first capture equal to $16 \mathrm{~cm}(\approx$ length at first sexual maturity) (Fig. 6). The figure showed that the maximum (Y/R)' was obtained at $\mathrm{E}_{\mathrm{MSY}}=0.61$ which is nearly the same as the current one. Both of $\mathrm{E}_{0.1}$ and $E_{0.5}$ were estimated. The obtained values of $E_{0.1}$ and $E_{0.5}$ were 0.52 and 0.36 respectively. This means that, the present level of $\mathrm{L}_{c}$ is not the optimum $\mathrm{L}_{c}$ of this fish species and it must be about $16 \mathrm{~cm}$.

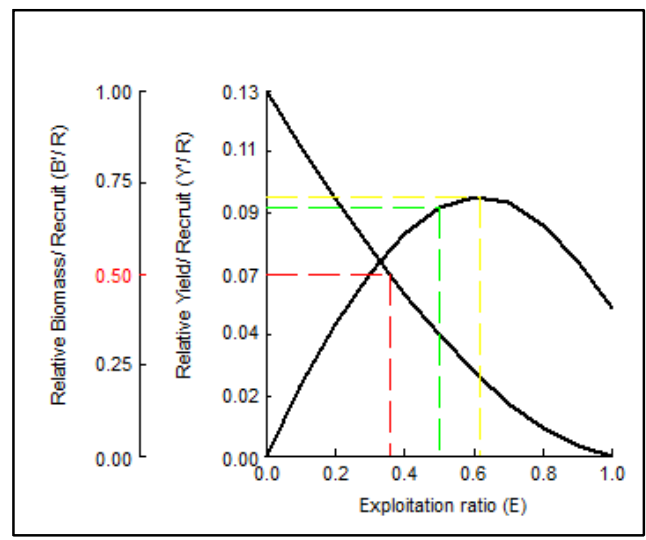

Fig. 6: Per-recruit analysis of Solea solea from Alexandria using $\mathrm{L}_{\mathrm{c}}=\mathrm{L}_{\mathrm{m}}$.

\section{Conclusion and recommendations}

The results showed that the stock of $S$. solea at Alexandria was overexploited. For the management purpose, the current exploitation rate must be reduced from 0.69 to 0.36 . This means that the present level of exploitation should be decreased by about $49 \%$ to maintain a sufficient spawning biomass as well as the length at first capture should be raised from $14.2 \mathrm{~cm}$ to about $16 \mathrm{~cm}$.

Accordingly, it should be control mesh size of nets used, control gear types used, protecting the spawning stock through implementing marine protected areas or closed seasons during the spawning, continue the study to assess and manage the different fish stocks exploited by trawling. Finally, the fisheries recording system should be improved.

\section{REFERENCES}

Beverton, R. J. H. and Holt, S. J. (1966). Manual of methods for fish stock assessment. Part 2. Tables of yield functions. FAO Fish. Tech. Pap./ FAO Doc. (38) Rev. 1: 67pp. 
El-Gammal, F.I.; El-Etreby, S. and Mahmoud, M. (1994). Estimation of mortality and yield per recruit of Solea solea (Linnaeus, 1758) in lake Bardawil, Egypt. Bull. Inst. Oceanogr. Fish., 20: 175-184.

Gulland, J. A. (1971). The fish resources of the Ocean. West Byfleet, Surrey, Fishing News, Ltd., FAO, 255 pp.

Jones, R. and Van Zalinge, N. P. (1981). Estimates of mortality rate and population size for shrimp in Kuwait waters. Kuwait Bull. Mar. Sci., 2: 273-288.

Mehanna, S. F. (2007). Stock assessment and management of the Egyptian sole Solea aegyptiaca Chabanaud, 1927 (Osteichthyes: Soleidae), in the Southeastern Mediterranean, Egypt in the Eastern Mediterranean (Port Said region), Egypt. Turk. J. Zool., 31: 379-388.

Mehanna, S. F. and Haggag, H. M. (2010). Port Said Fisheries: current status, assessment and management. 3rd International conference on Fisheries and Aquaculture, 29 November-1December, Cairo, Egypt. www.cabdirect.com.

Mehanna, S. F. and Salem, M. (2012). Fisheries regulations for the common sole Solea solea (Soleidae) at Bardawil lagoon, Mediterranean coast of Sinai, Egypt. (In press).

Mehanna, S. F.; Abo Elregal, M. and Aid, N.M. (2015). Age and Growth of the Common Sole Solea solea From Egyptian Mediterranean coast off Alexandria $19^{\text {th }}$ Conference of the Egyptian Society for Fisheries Development, 18 March, Ain Shams University, Egypt.

Mehanna, S. F.; Hegazi, M. M. and Mohamed, S. S. (2013). Age and growth based on the otolith readings of the common sole Solea solea from Bardawil lagoon, Mediterranean Sea. Journal of Environmental Sci., 1: 284-297.

Mehanna. S. F.; El-Aiatt, A. A. and Salem, M. (2011). An investigation of the impacts of shrimp bottom trawling on the Bardawil lagoon fisheries, Egypt. Egyp. J. Aquat. Biol. \& Fish., 15 (3): 369-378.

Pauly, D. (1980). On the interrelationships between natural mortality, growth parameters and mean environmental temperature in 175 fish stocks. J. Cons. CIEM, 39 (3): 175-192.

Pauly, D. (1983). Length-converted catch curves. A powerful tool for fisheries research in the tropics. Part 1. ICLARM Fishbyte, 1: 9-13.

Pauly, D. (1984). Length-converted catch curves. A powerful tool for fisheries research in the tropics. (part II) . ICLARM Fishbyte, 2 (1): 17-19.

Pauly, D. and Soriano, M. L. (1986). Some practical extensions to Beverton and Holt's relative yield-per-recruit model. In: J. L. Maclean; Dizon, L. B. and Hosillo, L. V. (eds.). The First Asian Fisheries Forum. 491-496.

Ricker, W. E. (1975). Computation and interpretation of biological statistics of fish populations. Bull. Fish. Res. Board Can., 191: 1-382.

Salman, (2014). Fisheries characteristics and population dynamics of commercial species of family Soleidae in Bardawil lagoon, North Sinai, Egypt (MSc.) Thesis, Sci. Fac. Suez Canal Univ.

Tanaka, S. (1960). Studies on the dynamics and the management of fish population. Bull.Tokai Reg. Fish. Res. Lab., 28: 1-200.

Ursin, E. (1967). A mathematical model of some aspects of fish growth, respiration and mortality. J. Fish. Res. Bd. Can., 24: 2355-2453. 


\section{ARABIC SUMMARY} الاطوال الحاسمة ومعدلات النفوق والانتاج النسبي لكل جيل لاسماكت موسي الثائعة (سوليا سوليا) في البحر

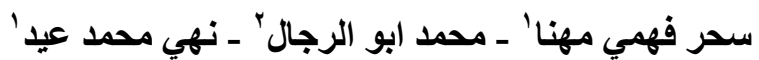

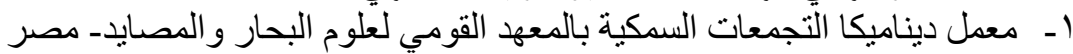

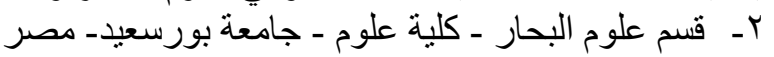

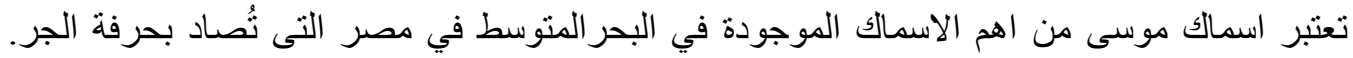

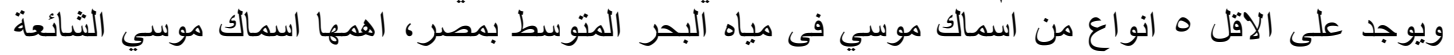

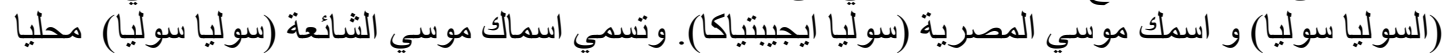

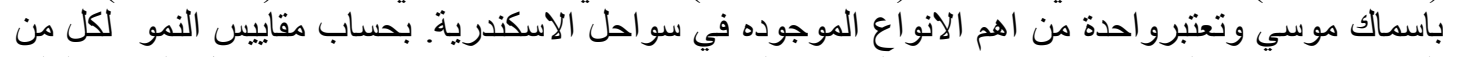

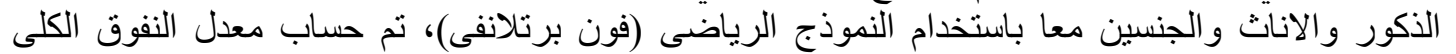

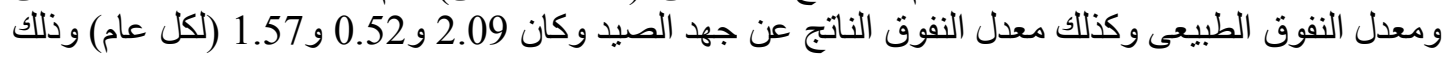

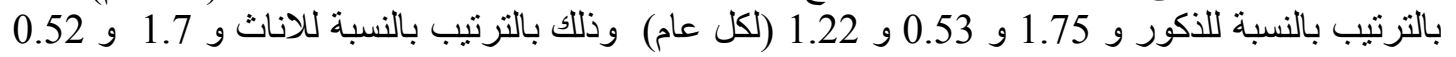

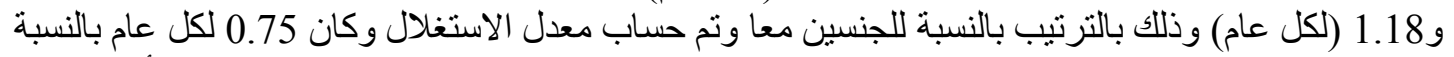

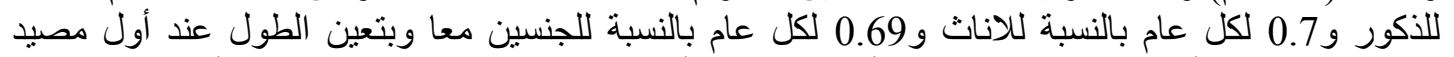

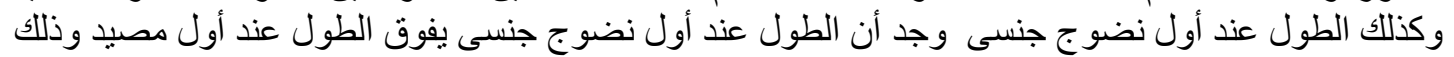

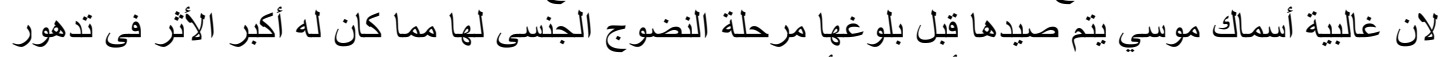

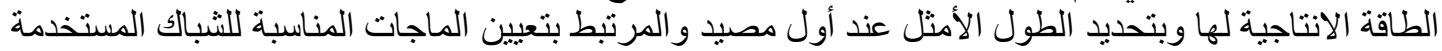

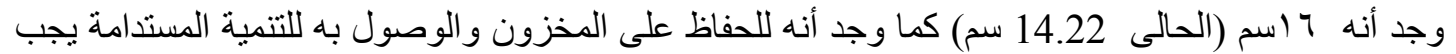
خفض معدل الاستغلال و المرتبط بمجهود الصيد الى نصف معدله الحالى تقريبا. 